\title{
EFFECT OF NITROGEN RATES AND ITS TIME OF APPLICATION ON PRODUCTIVITY OF SUGAR BEET UNDER SPRINKLE IRRIGATION IN NEWLY RECLAIMED SOILS Mahmoud, E. A. and M.I.Masri Agronomy Department, Faculty of Agric., Cairo Univ., Giza, Egypt
}

\begin{abstract}
Two field experiments were conducted at Sedment El-Gabal location, BeniSweif Governorate during 2007/2009 seasons to study the response of sugar beet yield and some of its attributes under sprinkle irrigation to different $\mathrm{N}$ rates; 100,120 , 140 and $160 \mathrm{~kg} \mathrm{~N} / \mathrm{fed}$ and its time of application viz., split application in two equal doses, at 4- and at 8-leaf stage, or in three equal doses, 1/3 at 4- leaf stage, 1/3 at 8leaf stage and $1 / 3$ three weeks later, or dividing the rate into 4 equal doses and added $1 / 4$ at 4 - leaf stages, $1 / 4$ at 8 - leaf stage, $1 / 4$ three weeks later and 1/4 three weeks after the last. A split plot design with four replications was used, where $\mathrm{N}$ rates were allocated in the main plots and time of $\mathrm{N}$ application was distributed at random in the subplots.

Results obtained from this study revealed that increasing $\mathrm{N}$ rates from 100 up to $160 \mathrm{~kg} \mathrm{~N} /$ fed significantly increased root weight by $16.52 \%$ and $24.77 \%$, number of plants at harvest by 4.05 and 2.89 thousand plants/fed and root yield by 7.22 and 8.34 tons/fed in the first and second seasons, respectively. Excessive $\mathrm{N}$ rate lowered beet quality in terms of sucrose content, juice purity and extractable sucrose. Extractable sugar yield increased by increasing $\mathrm{N}$ rates from 100 to $120 \mathrm{Kg} / \mathrm{fed}$. Such increase amounted to $29.08 \%$ in the first season and $31.97 \%$ in the second one. Additional increasing in nitrogen rate beyond $120 \mathrm{~kg} \mathrm{~N} / \mathrm{fed}$ had no significant effect on sugar yield.

Splitting $\mathrm{N}$ rate into 4 equal doses significantly increased weight of individual root and number of plants/fed at harvest. Late $\mathrm{N}$ application in favour of $\mathrm{N}$ splitted into 4 doses gave the highest root yield/fed. On the other hand, early application and splitting $\mathrm{N}$ in two equal doses at 4 -and at 8-leaf stage improved beet quality traits in terms of sucrose $\%$, purity $\%$ and extractable sucrose $\%$.

Splitting $160 \mathrm{~kg} \mathrm{~N} /$ fed into 4 equal doses gave the highest root yield, while splitting $120 \mathrm{~kg} \mathrm{~N} /$ fed into 4 equal doses was recommended for high sugar yield/fed. Keywords: Beta vulgaris L., Sprinkle irrigation, N rate, Time of application, Quality traits, Sugar yield
\end{abstract}

\section{INTRODUCTION}

The proper management of nitrogen fertilizer is a major factor in maximizing the production of sugar beet (Beta vulgaris L.). Supplies of $\mathrm{N}$ must be readily available during early and mid-season in order to promote root and top growth. However, beet plants must become deficient in $\mathrm{N}$ prior to harvest to attain the maximum sucrose concentration (Lauer, 1995). Widely different optimum rates of $\mathrm{N}$ have been reported in the literature. Halverson and Hartman (1980) reported that optimum rates as high as $390 \mathrm{Kg} / \mathrm{ha}$, while Carter and Traveller (1981) found that the optimum N level was $240 \mathrm{Kg} / \mathrm{ha}$. Kamel at el... (1989) and Ramadan (1997) found that root yield responded to $\mathrm{N}$ rate up to $90 \mathrm{Kg} / \mathrm{fed}$. Sharif and Eghbal (1994) conducted field trials on 
loamy clay soil where 7 Germen sugar beet cultivars were given from zero up to $150 \mathrm{Kg} \mathrm{N} / \mathrm{ha}$. They found that sugar yields increased with increasing $\mathrm{N}$ rate up to $150 \mathrm{Kg} / \mathrm{ha}$. Total soluble solids and juice purity \% decreased with increasing $\mathrm{N}$ rates. El-Hennawy et al. (1998) reported that increasing $\mathrm{N}$ rate up to $120 \mathrm{Kg} / \mathrm{fed}$ increased individual root weight by 166 and $181 \mathrm{~g}$ in the two growing seasons of study, respectively. Excessive $\mathrm{N}$ application lowered beet quality in terms of root sucrose content and recoverable sugar per ton of beet. Recoverable sugar yield followed a production pattern similar to root yield with maximum sugar yield and profits at $90 \mathrm{Kg} \mathrm{N} / \mathrm{fed}$. Number of plants at harvest was not significantly affected by $\mathrm{N}$ rates. Mahmoud et al. (1999) found that application of $100 \mathrm{Kg} \mathrm{N} / \mathrm{fed}$ produced the heaviest roots, the highest number of roots at harvest, the highest yields of roots, and sugar, while quality traits in terms of sucrose, purity and recoverable sugar percentage were decreased with high $\mathrm{N}$ rate. Shalaby et al. (2003) and Ramadan (2005) reported that applying $100 \mathrm{Kg} \mathrm{N} / \mathrm{fed}$ gave the highest chemical constituents of fresh beet root. They added that increasing $\mathrm{N}$ rate up to $120 \mathrm{Kg} / \mathrm{fed}$ increased root and sugar yields/fed. However, sucrose and purity percentages as well as sucrose loss to molasses were decreased as $\mathrm{N}$ rates increased up to $120 \mathrm{Kg} / \mathrm{fed}$. Ismail and Abo El-Ghit (2005) found that application of $155 \mathrm{Kg} \mathrm{N} / \mathrm{fed}$ significantly increased root fresh weight/plant by 52.57 and $30.03 \%$ and root yield by 12.28 and $10.12 \%$, while sucrose percentage was reduced by 11.11 and $14.63 \%$ in the first and second seasons, respectively. Masri (2008) in a sandy loam soil reported that application of $120 \mathrm{Kg} \mathrm{N} / \mathrm{fed}$ was recommended for sucrose content, purity, extractable sucrose and sugar yield.

Time of $\mathrm{N}$ application plays a great role in increasing the effectiveness of a given rate of $\mathrm{N}$. Little is know about the response of beet to different time of nitrogen application. In this connection, Carter and Traveller (1981) found that $\mathrm{N}$ application until mid - season caused a greater proportion of the photosynthates to be used for the continuity of top growth at the expense of dry matter and sucrose accumulation in the roots. Moreover, lat $\mathrm{N}$ application reduced sucrose and increased impurities in the beet roots and reduced extractability of stored sucrose.Abdel-Hafeez et al. (1984) found that no significant differences in root and sugar yields from splitting $\mathrm{N}$ at thinning ( at 4-leaf stage) and or one month or two months after thinning. However, sucrose content and purity decreased with the late application of nitrogen. Top yield increased with the delay of $\mathrm{N}$ application. Anderson and Petersson (1988) investigated the value of applying $N$ in split doses to increase sucrose production and decrease top growth and impurities of sugar beet. They added that $30-300 \mathrm{Kg} \mathrm{N} / \mathrm{ha}$ in doses of 30,60 and $90 \mathrm{Kg}$ over 16 weeks each year for 3 years on very fine sandy loam soils. They found that delaying $\mathrm{N}$ supply by splitting fertilizer application favoured root development and sucrose production but did not affect top growth. Zalat and Saif (1997) applyed $\mathrm{N}$ at sowing and at $60,80,100,120$ and 140 days after sowing. They found that the highest root and sugar yields resulted from $\mathrm{N}$ applied 80 days after sowing, while sucrose percentage was highest when $\mathrm{N}$ was applied at 100 days after sowing. Late $\mathrm{N}$ application (140 days after sowing) gave the highest top yield. Abdou (2000) and leilah et al. (2005) reported that splitting 
$\mathrm{N}$ into 4 portions of $45,60,75$ and 90 days from planting were associated with the highest values of root length and diameter, number of plants at harvest, root fresh weight as well as root and sugar yields. Early splitting into two equal portions 45 and 60 days from planting recorded the highest sucrose content and total soluble solids. Addling $\mathrm{N}$ in four portions gave the highest purity, root yield, top yield and sugar yield.

The purpose of this article was to study the response of sugar beet to nitrogen rates and its time of application in newly reclaimed soil.

\section{MATERIALS AND METHODS}

Two field experiments were conducted at Sedment location, BeniSweif Governorate during 2007/2008 and 2008/2009 season to find out the most suitable $\mathrm{N}$ rate and time of application and their effect on sugar yields and some of its attributes under sprinkling irrigation. Four nitrogen rates; $100,120,140$ and $160 \mathrm{Kg} \mathrm{N} / \mathrm{fed}$ in the form of ammonium nitrate $(33 \% \mathrm{~N})$ were used. Three dates of $\mathrm{N}$ time application were included in this experiment. The first date included dividing the nitrogen dose into two equal parts and applied the first half at 4-leaf stage and the second half at 8- leaf stage. The second date included dividing the $\mathrm{N}$ rate into three equal parts and applied them $1 / 3$ at 4 - leaf stage, $1 / 3$ at 8 - leaf stage and $1 / 3$ three weeks latter. The third one included dividing the $\mathrm{N}$ rate into four equal parts and added $1 / 4$ at 4 - leaf stage $+1 / 4$ at 8 - leaf stage $+1 / 4$ three weeks latter $+1 / 4$ three weeks after. Preceding crops and soil characteristics of sugar beet experimental fields during 2007/08 and 2008/09 seasons

A split plot design with four replications was used. Nitrogen rates were allocated to the main plots, while application time was distributed at random in the subplots. Sugar beet cultivar "Pleno" was sown on ridges 60 $\mathrm{cm}$ apart and $17.5 \mathrm{~cm}$ between hills. Each subplot included 5 ridges each is 4 $\mathrm{m}$ in length. Therefore each subplot size was $12 \mathrm{~m}^{2}$. Sugar beet seeds were sown on the second week of October of each year. Phosphorous in the form of super phosphate $(15.5 \%)$ at rate of $30 \mathrm{Kg} \mathrm{P}_{2} \mathrm{O}_{5} / \mathrm{fed}$ was added before sowing and during land preparation. Potassium in the form of potassium sulfate $(48 \%)$ was added at the rate of $48 \mathrm{Kg} \mathrm{K}$ O/fed with the first dose of $\mathrm{N}$. Thinning took place to one plant/hill at 4-leaf stage (4 weeks from planting). Other culture practice procedures were done as recommended.

Sugar beet was topped and harvested by hand on May $15^{\text {th }}$ ( 210 days from planting). Roots were harvested from each plot. Weight per plot was obtained and used to calculate root on a per-feddan basis. Ten root pulp samples were taken at random from each plot to determine juice quality traits. Total soluble solids (TSS) was determined by using digital refractometer model PR1,ATAGO, Japan. Sucrose \% was determined polarimetrically on lead acetate extract of fresh macerated roots according to Carruthers and Oldfield (1960). Purity was calculated by dividing sucrose by TSS. Extractable sucrose\% was calculated using the following equation from Dexter et al.., (1967): 
Extractable sucrose $\%=[$ sucrose $\%-0.3][1-(1.667(\underset{\text { purity }}{100 \text {-purity }})]$

Sugar yield was calculated according the following equation:

Sugar yield ton fed ${ }^{-1}=$ root yield ton fed $^{-1} \times$ Extractable sucrose $\%$

Collected data were subjected to normal statistical analysis as shown by Snedecor and Cochran (1989). Treatment mean comparisons were made using least significant difference(LSD) at $5 \%$ level of probability.

Table 1. Preceding crops and soil characteristics of sugar beet experimental fields during $2007 / 08$ and $2008 / 09$ seasons

\begin{tabular}{|c|c|c|}
\hline & $2007 / 2008$ & 2008/2009 \\
\hline Preceding crop & Maize & Follow \\
\hline Soil sample date & 15 Oct. & 15 Oct. \\
\hline Soil texture & Sandy loam & Sandy loam \\
\hline pH & 8.60 & 9.00 \\
\hline E.C (m/cm) & 2.50 & 2.80 \\
\hline $\mathrm{Na}(\mathrm{mq} / \mathrm{l})$ & 1.00 & 1.20 \\
\hline $\mathrm{Cl}(\mathrm{mq} / \mathrm{l})$ & 24.00 & 26.4 \\
\hline $\mathrm{CaCO}_{3} \%$ & 28.20 & 30.00 \\
\hline $\mathbf{N}\left(\mathbf{m g ~ k g}^{-1}\right)$ & 20.00 & 18.00 \\
\hline$P\left(\mathrm{mg} \mathrm{kg}^{-1}\right)$ & 28.00 & 30.00 \\
\hline $\mathrm{K}\left(\mathrm{mg} \mathrm{kg} \mathbf{~}^{-1}\right)$ & 168.00 & 174.00 \\
\hline $\mathrm{Fe}\left(\mathrm{mg} \mathrm{kg}^{-1}\right)$ & 8.60 & 9.20 \\
\hline $\mathrm{Zn}\left(\mathrm{mg} \mathrm{kg} \mathbf{~}^{-1}\right)$ & 0.56 & 0.60 \\
\hline $\operatorname{Mn}\left(\mathrm{mg} \mathrm{kg}^{-1}\right)$ & 4.70 & 5.00 \\
\hline
\end{tabular}

\section{RESULTS AND DISCUSSION}

\section{A-Effect of nitrogen rates:}

Data presented in Table 2 show the effect of $\mathrm{N}$ rates on yield, yield component and juice quality traits in both seasons of study.

Results revealed that $\mathrm{N}$ rates exhibited significant effect on root fresh weight in both seasons. A gradual increase in root weight as $\mathrm{N}$ rate increased up to $160 \mathrm{Kg} / \mathrm{fed}$ was recorded. The increase amounted to $10.52 \%, 13.46 \%$ and $16.52 \%$ in the first season and $6.96 \%, 16.33 \%$ and $24.77 \%$ in the second season as $N$ rate increased from 100 to 120,140 and $160 \mathrm{Kg} / \mathrm{fed}$, respectively. This increase in root weight is mainly due to the role of $\mathrm{N}$ in stimulating the meristematic growth activity which contributes to the increase in number of cells in additions to cell enlargement. Similar findings were reported by El-Hennawy et al. (1998) and Ismail and Abo El- Ghit (2005).

Number of plants at harvest was significantly affected by $N$ rates in both seasons. Increasing $N$ rate up to $160 \mathrm{Kg} / \mathrm{fed}$ increased number of plants at harvest by 4.05 and 2.89 thousand plants/fed as compared to application of $100 \mathrm{~kg} \mathrm{~N} / \mathrm{fed}$ in the first and second seasons, respectively. This result is in agreement with that obtained by Mahmoud et al. (1999).

Significant differences among $\mathrm{N}$ rates in their effect on root yield were recorded in both seasons (table 2). Increasing $\mathrm{N}$ rate from 100 to $120 \mathrm{~kg} / \mathrm{fed}$, from 120 to $140 \mathrm{~kg} / \mathrm{fed}$ and from 140 to $160 \mathrm{~kg} / \mathrm{fed}$ increased root yield by 
about $14.53 \%, 10.81 \%$ and $7.20 \%$ in the $1^{\text {st }}$ season, corresponding to $16.35 \%, 7.20 \%$ and $11.42 \%$ in the $2^{\text {nd }}$ season, respectively. The increase in root yield accompanying high $\mathrm{N}$ rate might have been due to the increase in number of harvested root as well as individual root weight as mentioned before. Such results are in accordance with those reported by Halverson and Hartman (1980), Sharif and Eghbal (1994), El-Hennawy et al. (1998), Shalaby et al. (2003), Ismail and Abo El- Ghit (2005) and Masri (2008).

Table 2. Effect of nitrogen level on sugar beet yield and some of its attributes during 2007/2008 and 2008/2009 seasons.

\begin{tabular}{|c|c|c|c|c|c|c|c|}
\hline $\begin{array}{l}\text { Nitrogen } \\
\text { levels(kg/fed) }\end{array}$ & $\begin{array}{l}\text { Root } \\
\text { fresh } \\
\text { weight } \\
\text { (g) } \\
\end{array}$ & $\begin{array}{c}\text { Number of } \\
\text { plants/fed } x \\
10^{3}\end{array}$ & $\begin{array}{l}\text { Root yield } \\
\text { (ton/fed) }\end{array}$ & $\begin{array}{c}\text { Sucrose } \\
\%\end{array}$ & $\begin{array}{c}\text { Purity } \\
\%\end{array}$ & $\begin{array}{c}\text { Extractable } \\
\text { sucrose \% }\end{array}$ & $\begin{array}{c}\text { Sugar } \\
\text { yield } \\
\text { (ton/fed) }\end{array}$ \\
\hline & & & & & & & \\
\hline & \multicolumn{7}{|c|}{$2007 / 2008$ season } \\
\hline 100 & 834.44 & 23.89 & 20.03 & 19.24 & 82.56 & 12.29 & 2.51 \\
\hline 120 & 922.22 & 24.83 & 22.94 & 20.57 & 84.26 & 13.97 & 3.24 \\
\hline 140 & 946.67 & 26.78 & 25.42 & 19.20 & 82.34 & 12.16 & 3.21 \\
\hline 160 & 972.22 & 27.94 & 27.25 & 18.63 & 81.24 & 11.28 & 3.26 \\
\hline \multirow[t]{2}{*}{ LSD at $5 \%$} & 34.69 & 0.68 & 0.57 & 0.33 & 0.71 & 0.50 & 0.13 \\
\hline & \multicolumn{7}{|c|}{$2008 / 2009$ season } \\
\hline 100 & 830.00 & 25.72 & 21.41 & 19.42 & 83.01 & 12.61 & 2.69 \\
\hline 120 & 887.78 & 27.89 & 24.91 & 20.62 & 84.53 & 14.13 & 3.55 \\
\hline 140 & 965.56 & 27.44 & 26.70 & 19.16 & 83.31 & 12.57 & 3.42 \\
\hline 160 & 1035.56 & 28.61 & 29.75 & 18.73 & 81.79 & 11.60 & 3.59 \\
\hline LSD at $5 \%$ & 48.24 & 0.55 & 1.45 & 0.24 & 1.06 & 0.57 & 0.21 \\
\hline
\end{tabular}

Root quality traits, in terms of sucrose, purity and extractable sucrose percentage were significantly affected by varying $N$ rates in both seasons (table 2). Increasing $\mathrm{N}$ rate from 100 to $120 \mathrm{~kg} / \mathrm{fed}$ significantly increased sucrose by $1.33 \%$, purity by $1.70 \%$ and extractable sucrose by $1.68 \%$ in the first season, corresponding to $1.20 \%, 1.52 \%$ and $1.52 \%$ in the second season, respectively, thereafter further increase in $\mathrm{N}$ rate lowered beet quality. The lowest values of sucrose, purity and extractable sucrose resulted from $160 \mathrm{~kg} \mathrm{~N} / \mathrm{fed}$. The depressive effect of higher excessive $\mathrm{N}$ on beet quality coincides whit those reported by Carter and Traveller (1981), Kamel et al. (1989), Sharif and Eghbal (1994), El-Hennawy et al. (1998), Shalaby et al. (2003) and Ramadan (2005).

Results in table (2) cleared that sugar yield was significantly increased by increasing $\mathrm{N}$ rate from 100 to $120 \mathrm{Kg} / \mathrm{fed}$. These results were true in the two growing seasons. Such increase amounted to $29.08 \%$ in the first season and $31.97 \%$ in the second one. Additional increasing in nitrogen rate beyond $120 \mathrm{~kg} \mathrm{~N} / \mathrm{fed}$ had no significant effect on sugar yield in both seasons, since $120 \mathrm{~kg} \mathrm{~N} / \mathrm{fed}$ was at bar at $160 \mathrm{~kg} \mathrm{~N} / \mathrm{fed}$. It is worthy to mention that the reduction in quality traits (sucrose, purity and recoverable sucrose) accompanying higher $\mathrm{N}$ rates was compensated for higher root yield. Similar results were reported by Sharif and Eghbal (1994), El-Hennawy et al. (1998), Mahmoud (1999), Ramadan (2005) and Masri (2008). 


\section{B- Effect of time of $\mathrm{N}$ application:}

Data presented in the table (3) revealed that root fresh weight was significantly affected by time of $N$ application in both seasons. Split application of $\mathrm{N}$ in four equal doses produced the heaviest roots with an average of 948.34 and $1020.83 \mathrm{gm}$ in the first and second season, respectively, while the lowest values of root fresh weight resulted from $\mathrm{N}$ applied in two equal doses. This result is in agreement with those obtained by Abdou (2000) and leilah et al. (2005), who reported that late $\mathrm{N}$ application increased root weight of sugar beet.

Number of plants at harvest was significantly increased as $\mathrm{N}$ application was delayed. Splitting $N$ into 4 equal doses (at 4,8 leaf stage and 3 and 6 weeks later) resulted in the highest number of roots at harvest which exceeded that of $\mathrm{N}$ applied into two equal doses by $18.05 \%$ and $13.16 \%$ in the first and second seasons, respectively. Similar results were reported by Abdou (2000) and leilah et al. (2005).

Table 3. Effect of application time of nitrogen on sugar beet yield and some of its attributes during 2007/2008 and 2008/2009 seasons.

\begin{tabular}{|c|c|c|c|c|c|c|c|}
\hline $\begin{array}{l}\text { Time of } \\
\text { application }\end{array}$ & $\begin{array}{c}\text { Root } \\
\text { fresh } \\
\text { weight } \\
\text { (g) }\end{array}$ & $\begin{array}{c}\text { Number of } \\
\text { plants/fed } x \\
10^{3}\end{array}$ & $\begin{array}{c}\text { Root yield } \\
\text { (ton/fed) }\end{array}$ & $\begin{array}{c}\text { Sucrose } \\
\%\end{array}$ & $\begin{array}{c}\text { Purity } \\
\%\end{array}$ & $\begin{array}{l}\text { Extractable } \\
\text { sucrose \% }\end{array}$ & $\begin{array}{c}\text { Sugar } \\
\text { yield } \\
\text { (ton/fed) }\end{array}$ \\
\hline & \multicolumn{7}{|c|}{$2007 / 2008$ season } \\
\hline 2 & 879.17 & 23.54 & 20.78 & 20.20 & 84.52 & 13.84 & 2.95 \\
\hline 3 & 929.17 & 26.25 & 24.43 & 19.49 & 82.65 & 12.49 & 3.16 \\
\hline 4 & 948.33 & 27.79 & 26.52 & 18.54 & 80.63 & 10.94 & 3.06 \\
\hline \multirow[t]{2}{*}{ LSD at $5 \%$} & 28.70 & 0.81 & 0.94 & 0.18 & 0.46 & 0.24 & 0.13 \\
\hline & \multicolumn{7}{|c|}{ 2008/2009 season } \\
\hline 2 & 845.00 & 25.92 & 21.96 & 20.33 & 85.00 & 14.15 & 3.20 \\
\hline 3 & 923.33 & 27.00 & 25.02 & 19.52 & 83.12 & 12.72 & 3.26 \\
\hline 4 & 1020.83 & 29.33 & 30.09 & 18.60 & 81.36 & 11.32 & 3.48 \\
\hline LSD at $5 \%$ & 42.69 & 0.67 & 1.24 & 0.17 & 0.63 & 0.37 & 0.24 \\
\hline
\end{tabular}

Significant differences among times of $\mathrm{N}$ application in root yield/fed were reported in both seasons (Table 3 ). The highest root yield (26.52 and 30.09 ton/fed resulted from splitting $\mathrm{N}$ rate into 4 equal doses (at 4 and 8 leaf stage +3 and 6 weeks later) followed by splitting $N$ rate into 3 equal doses (24.43 and 25.02 ton/fed) and then splitting $\mathrm{N}$ rate into two equal doses ( 20.78 and 21.96 ton/fed) in the first and second seasons, respectively. It is worth mentioning that the increase in root yield/fed with the delay in $\mathrm{N}$ application might have resulted from the increase in number of roots at harvest as well as to the increase in individual root weight accompanying the delay of $\mathrm{N}$ application in sandy soil. The favorable impact of delayed $\mathrm{N}$ application on root production of sugar beet was also reported by Carter and Traveller (1981), Zalat and liala-Saif (1997), Abdou (2000) and leilah et al. (2005). 
Timing of $\mathrm{N}$ application exhibited significant effect on juice quality traits in both growing seasons (table 3). Early application of $\mathrm{N}$ improved beet quality. The highest sucrose, purity and Extractable sucrose percentage resulted from application of $1 / 2$ the dose at 4-leaf sage and the other $1 / 2$ dose at 8-leaf stage. Delaying $\mathrm{N}$ application lowered root quality traits. The lowest sucrose $(18.54$ and $18.60 \%)$ purity (80.63 and $81.36 \%)$ and Extractable sucrose (10.94 and $11.32 \%$ ) resulted from splitting $N$ into 4 equal doses in the first and second seasons, respectively. The depressive effect of late $\mathrm{N}$ application on beet quality was reported by Abdel-Hafeez et al. (1984), Anderson and Petersson (1988), Abdou (2000) and leilah et al. (2005).

Sugars yield/fed significantly responded to time of $\mathrm{N}$ application in both seasons. Early application of $\mathrm{N}$ at 4- and 8- leaf stages produced the lowest sugar yield per fed (2.95 and 3.20 ton/fed). Sugar yield increased with splitting $N$ into three equal doses (3.16 and 3.26 ton/fed) and with splitting it into four equal doses (3.06 and 3.48 ton/fed), in the first and second seasons, respectively. It is worth to mention that the reduction in juice quality traits (sucrose, purity and extractable sucrose) accompanying late $\mathrm{N}$ application was compensated for the increase in root yield/fed and finally sugar yield was increased. Similar results were obtained by Carter and Traveler (1981), Anderson and petersson (1988), and leilah et al. (2005).

\section{C- Effect of the interaction between rates and time of $\mathbf{N}$ application:}

Data presented in Table 4 indicated that root fresh weight was significantly affected by the interaction between $\mathrm{N}$ rate and time of its application in both seasons. The heaviest roots; 1003.33 and $1150.00 \mathrm{gm}$ resulted from applying 160 and $140 \mathrm{Kg} \mathrm{N}$ splitted into 4 equal doses in the $1^{\text {st }}$ and $2^{\text {nd }}$ seasons, respectively. $\mathrm{N}$-rate $\mathrm{x}$ time of application interaction exhibited significant effect on number of plans/fed at harvest. Applying 160 $\mathrm{Kg} \mathrm{N} / \mathrm{fed}$ splitted in 4 equal doses produced the highest number of plants at harvest being 31.00 and 30.67 thousand plants in the first and second seasons, respectively. The highest root yield/fed resulted from applying 140 and/or $160 \mathrm{Kg} \mathrm{N}$ splitted into 4 equal doses. Differences between 140 and $160 \mathrm{Kg} \mathrm{N}$ being significant only in the $1^{\text {st }}$ season (table 4). Data averaged over seasons (Fig. 1) indicated that splitting $160 \mathrm{~kg} \mathrm{~N} / \mathrm{fed}$ into 4 equal doses resulted in the highest root yield/fed.

$\mathrm{N}$-rate $\mathrm{x}$ time of $\mathrm{N}$ application had a significant effect on sucrose content. The highest sucrose content $(21.50$ and $21.57 \%)$ resulted from 120 $\mathrm{kg} \mathrm{N}$ splitted into two equal doses at 4-and 8-leaf stage (Table 4). Purity and extractable sucrose percentages were not significantly affected by the interaction between $\mathrm{N}$ rate and time of application. Results also revealed that splitting $120 \mathrm{~kg} \mathrm{~N} / \mathrm{fed}$ into 4 equal doses was recommended for high sugar yield /fed in both seasons. Data averaged over seasons revealed that Application of $120 \mathrm{~kg} \mathrm{~N} / \mathrm{fed}$ in two equal doses gave the highest values of sucrose percentage (Fig. 2) and extractable sucrose percentage (Fig. 3), while application the same rate of nitrogen at 4 equal doses gave the highest value of sugar yield/fed (Fig. 4). 
Table 4. Interaction effect between nitrogen levels and its time of application on sugar beet yield and some of its components in $2007 / 2008$ and $2008 / 2009$ seasons.

\begin{tabular}{|c|c|c|c|c|c|c|c|}
\hline \multirow{2}{*}{$\begin{array}{l}\text { Nitrogen } \\
\text { levels } \\
\text { (kg/fed) }\end{array}$} & \multirow{2}{*}{$\begin{array}{l}\text { Time of } \\
\text { application }\end{array}$} & \multicolumn{2}{|c|}{$\begin{array}{l}\text { Root fresh weight } \\
\text { (g) }\end{array}$} & \multicolumn{2}{|c|}{$\begin{array}{c}\text { Number of } \\
\text { plants/fed } \times 10^{3}\end{array}$} & \multicolumn{2}{|c|}{ Root yield (ton/fed) } \\
\hline & & $2007 / 08$ & $2008 / 09$ & $2007 / 08$ & $2008 / 09$ & $2007 / 08$ & $2008 / 09$ \\
\hline \multirow{3}{*}{100} & 2 & 803.33 & 790.00 & 21.50 & 24.67 & 17.33 & 19.53 \\
\hline & 3 & 880.00 & 866.67 & 25.33 & 26.33 & 22.33 & 22.88 \\
\hline & 4 & 820.00 & 833.33 & 24.83 & 26.17 & 20.43 & 21.81 \\
\hline & & & & & & & \\
\hline \multirow{3}{*}{120} & 2 & 876.67 & 816.67 & 22.50 & 26.17 & 19.72 & 21.33 \\
\hline & 3 & 913.33 & 880.00 & 25.67 & 26.33 & 23.45 & 23.17 \\
\hline & 4 & 976.67 & 966.67 & 26.33 & 31.17 & 25.67 & 30.23 \\
\hline \multirow{3}{*}{140} & 2 & 906.67 & 820.00 & 24.50 & 26.33 & 22.19 & 21.69 \\
\hline & 3 & 940.00 & 926.67 & 26.83 & 26.67 & 25.24 & 24.74 \\
\hline & 4 & 993.33 & 1150.00 & 29.00 & 29.33 & 28.81 & 33.67 \\
\hline \multirow{3}{*}{160} & 2 & 930.00 & 953.33 & 25.67 & 26.50 & 23.89 & 25.29 \\
\hline & 3 & 983.33 & 1020.00 & 27.17 & 28.67 & 26.70 & 29.29 \\
\hline & 4 & 1003.33 & 1133.33 & 31.00 & 30.67 & 31.17 & 34.67 \\
\hline & & & & & & & \\
\hline
\end{tabular}

Table 4. Continued.

\begin{tabular}{|c|c|c|c|c|c|c|c|c|c|}
\hline \multirow{2}{*}{$\begin{array}{l}\text { Nitrogen } \\
\text { level } \\
(k g / f e d)\end{array}$} & \multirow{2}{*}{$\begin{array}{lr}\text { Time of } \\
\text { application }\end{array}$} & \multicolumn{2}{|c|}{ Sucrose \% } & \multicolumn{2}{|c|}{ Purity \% } & \multicolumn{2}{|c|}{$\begin{array}{c}\text { Extractable } \\
\text { sucrose } \%\end{array}$} & \multicolumn{2}{|c|}{$\begin{array}{l}\text { Sugar yield } \\
\text { (ton/fed) }\end{array}$} \\
\hline & & $2007 / 08$ & $2008 / 09$ & $2007 / 08$ & 2008/09 & $2007 / 08$ & $2008 / 09$ & $2007 / 08$ & $2008 / 09$ \\
\hline \multirow{3}{*}{100} & 2 & 20.00 & 20.43 & 84.03 & 85.14 & 13.46 & 14.27 & 2.33 & 2.79 \\
\hline & 3 & 19.53 & 19.43 & 82.77 & 82.70 & 12.56 & 12.46 & 2.87 & 2.85 \\
\hline & 4 & 18.20 & 18.40 & 80.89 & 81.18 & 10.85 & 11.10 & 2.32 & 2.42 \\
\hline \multirow{3}{*}{120} & 2 & 21.50 & 21.57 & 86.00 & 86.27 & 15.45 & 15.62 & 3.05 & 3.41 \\
\hline & 3 & 20.70 & 20.63 & 84.37 & 84.56 & 14.10 & 14.15 & 3.38 & 3.35 \\
\hline & 4 & 19.50 & 19.67 & 82.41 & 82.75 & 12.36 & 12.63 & 3.29 & 3.89 \\
\hline \multirow{3}{*}{140} & 2 & 20.03 & 19.90 & 84.29 & 85.30 & 13.60 & 13.96 & 3.15 & 3.17 \\
\hline & 3 & 19.10 & 19.23 & 82.45 & 83.62 & 12.13 & 12.75 & 3.18 & 3.28 \\
\hline & 4 & 18.47 & 18.33 & 80.29 & 81.01 & 10.73 & 10.98 & 3.31 & 3.81 \\
\hline \multirow{3}{*}{160} & 2 & 19.27 & 19.43 & 83.77 & 83.29 & 12.84 & 12.73 & 3.26 & 3.41 \\
\hline & 3 & 18.63 & 18.77 & 81.01 & 81.59 & 11.17 & 11.52 & 3.20 & 3.54 \\
\hline & 4 & 18.00 & 18.00 & 78.95 & 80.49 & 9.83 & 10.54 & 3.31 & 3.81 \\
\hline LSD at $5 \%$ & & 0.35 & 0.35 & NS & NS & NS & NS & 0.26 & 0.40 \\
\hline
\end{tabular}


J. Agric. Sci. Mansoura Univ., 34 (8), August, 2009

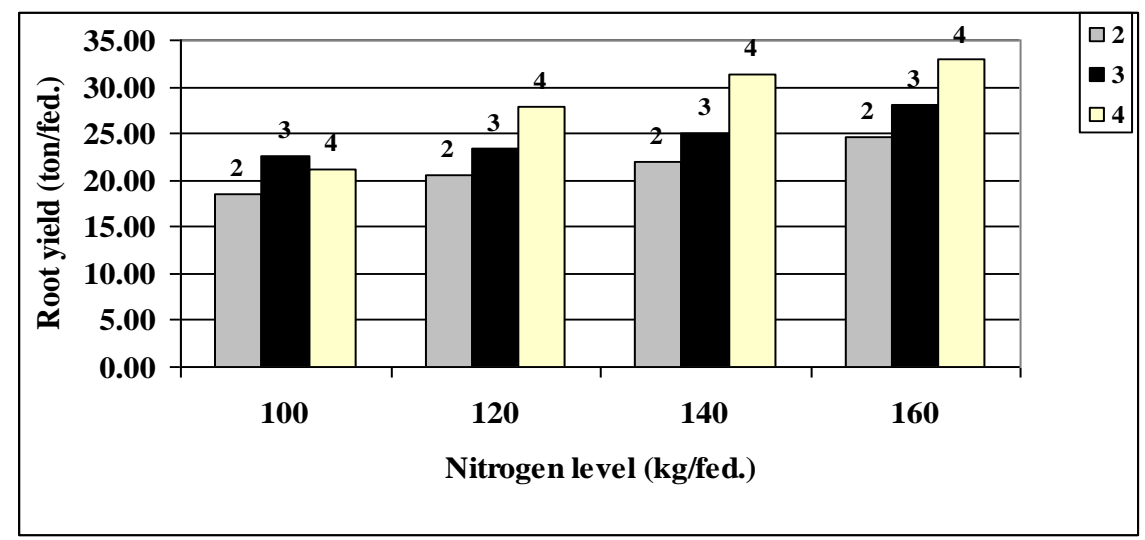

2 = Splitting $\mathbf{N}$ rate into 2 equal doses, 3 = Splitting $\mathbf{N}$ rate into 3 equal doses and 4 = Splitting $\mathbf{N}$ rate into 4 equal doses.

Fig. 1. Root yield of sugar beet as affected by the interaction between nitrogen levels and its time of application ( combined over years).

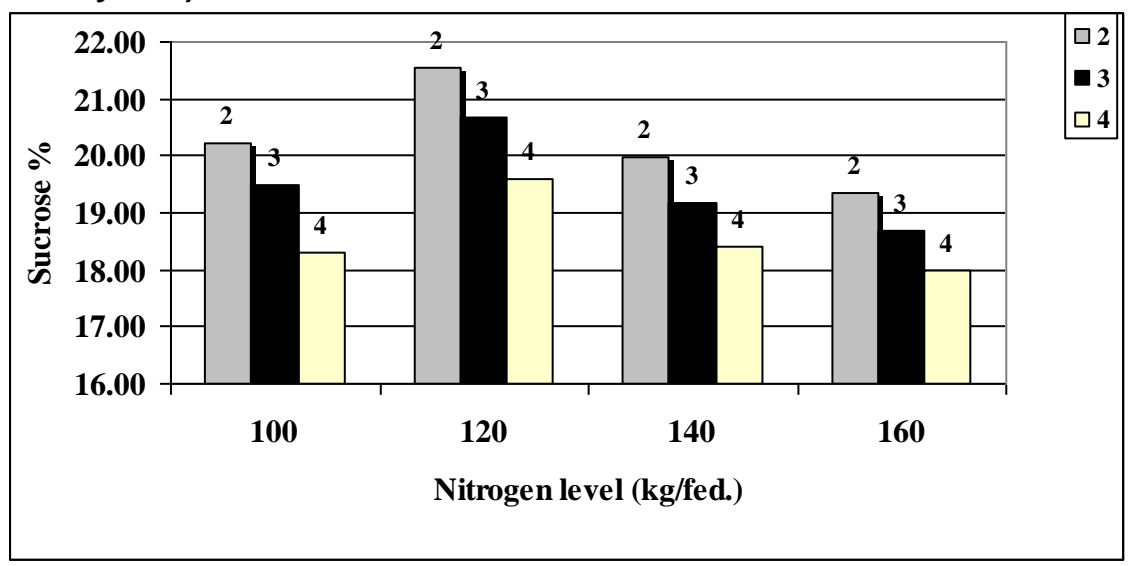

Fig. 2. Sucrose content of sugar beet as affected by the interaction between nitrogen levels and its time of application (combined over years). 


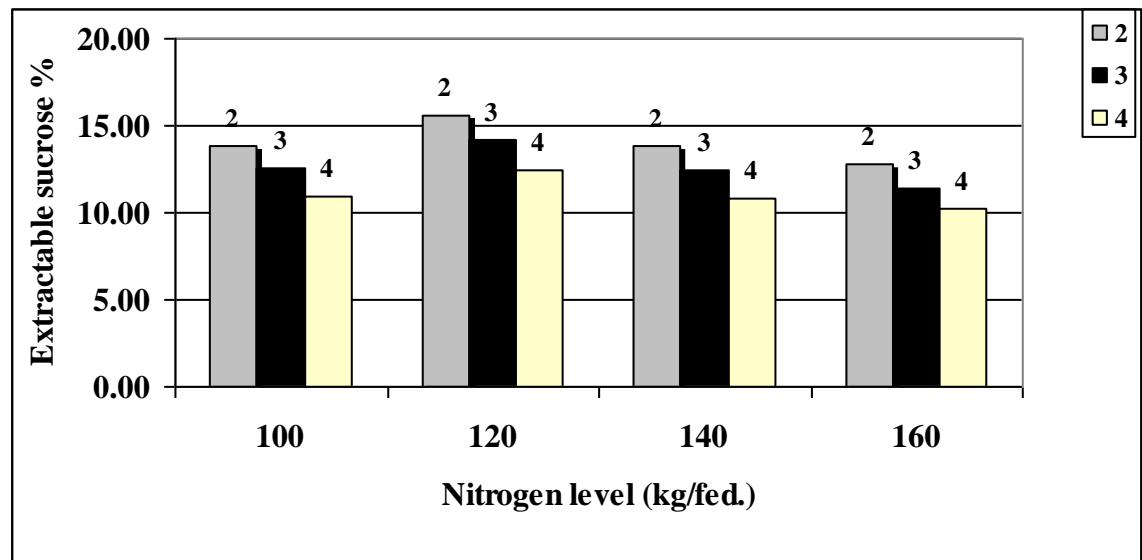

Fig. 3. Extractable sucrose of sugar beet as affected by the interaction between nitrogen levels and its time of application (combined over years).

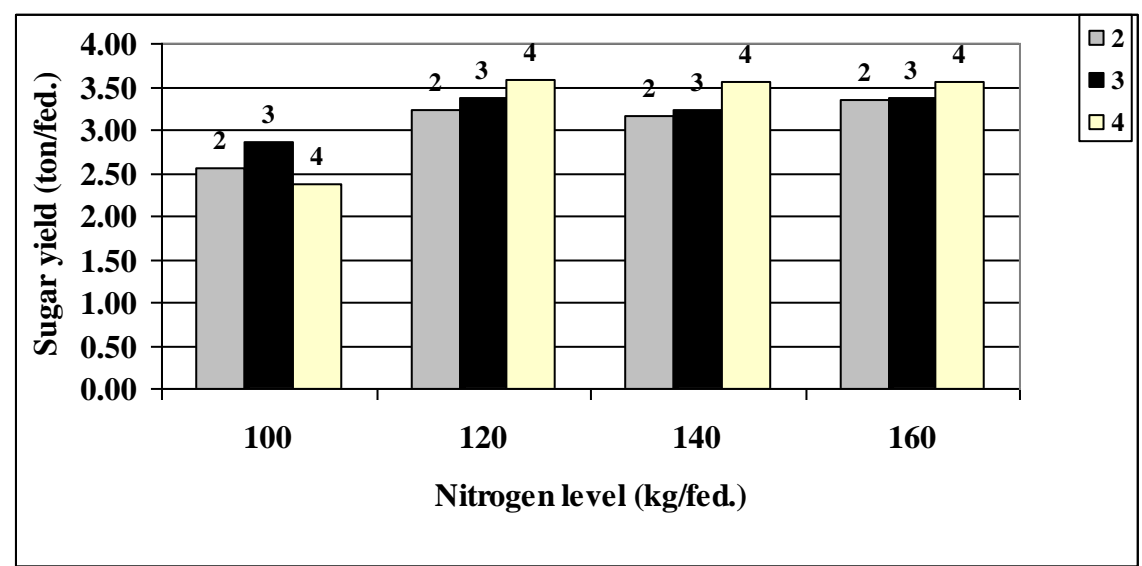

Fig. 4. Sugar beet yield as affected by the interaction between nitrogen level and its time of application (combined over years).

\section{REFERENCES}

Abd El-Hafeez, A.A.; M.S. Osman; N.F. Dawalla and A.F. Abdalla (1984). Effect of population density and time of nitrogen application on some sugar beet varieties. Bull. Fac. Agric., Cairo Univ., 35(1): 141-150.

Abdou, M. A. E. (2000). Effect of planting date, plant population and fertilization on sugar beet productivity under newly reclaimed sandy soils. Ph.D Thesis, Fac. Agric. Mansoura Univ.

Anderson, F.N. and G.A. Petersson (1988). Effect of incrementing nitrogen application on yield of sugar beet. Agron. J., 80(5):709-712.

Carruthers, A. and J.F.T. oldfield (1960). Methods for the assessment of beet quality. Int. Sugar J., 63: 72-74, 103-105, 137-139. 
Carter, J.N. and D.J. Traveller (1981). Effect of time and amount of nitrogen uptake on sugar beet growth and yield. Agron. J., 73:663-671.

Dexter, S. T.; M. G. Frankes and F.W. Snyder (1967). A rapid and practical method of determining of extractable white sugars as may be applied to the evaluation of agronomic practices and grower deliveries in the sugar beet industry. J. Am. Soc. Sugar Beet Technol., 14: 433 - 454.

El-Hennawy,H.H.; B.S.H.Ramadan and E.A.Mahmoud (1998). Response of sugar beet to nitrogen fertilization levels and its time of application J.Agric.Sci.Mansoura.Univ., 23 (3): 969-979.

Halverson, A. and G.P. Hartman (1980). Response of several sugar beet cultivars to $\mathrm{N}$ fertilization. Yield and crown tissue production. Agron. J., 72: 665-669.

Ismail, A.A.A. and R.A. Abo El-Ghit (2005). Effect of nitrogen sources and levels on yield and quality of sugar beet. Egypt. J. Agric. Res., 83(1): 229-239.

Kamel, M.S.; E.A. Mahmoud; A.A Abdel-Hafeaz; E.O. Abustait and B.S. Hassanein (1989). Effect of plant density, thinning time and nitrogen fertilization on growh, yield and quality of sugar beet. Assuit J. Agric. Sci., 20:225-238.

Lauer, J. G. (1995). Plant density and nitrogen rate effects on sugar beet yield and quality early in harvest. Agron. J., 87: $586-591$.

Leilah, A. A.; M. A. Badawi and E. M. Said (2005). Effect of planting dates, plant population and nitrogen fertilization on sugar beet productivity under the newly reclaimed sandy soils in Egypt. Scientific J. King Faisal Univ. (Basic and Appl. Sci.), 6: $95-110$.

Mahmoud, E.A.; El.M.A. El-Metwally and M.E.M Gobarh (1999). Yield and quality of some multigerm sugar beet as affected by plant densities and nitrogen levels. J.Agric.Sci. Mansoura.Univ., 24 (9): 4499-4516.

Masri, M.I. (2008). Effect of nitrogen level and planting density on sugar beet yield and its attributes. Egypt J. Agron., 33(2): 119-136.

Ramadan, B.S.H. (1997). Sugar beet yield and quality as affected by nitrogen and potassium fertilization. Pak. Sugar Tech.12(1):8-13.

Ramadan, B.S.H. (2005). Effect of nitrogen fertilization and harvest date on yield, yield components and quality of sugar beet J. Agric. Sci. Mansoura.Univ., 30 (2): 773-783.

Sharif,A.F. and K. Eghbal (1994). Yield analysis of seven sugar beet varieties under different levels of nitrogen in a dry region of Egypt. Agribiological research $47(3 / 4): 231-241$.

Shalaby, M.T.; M.B. Doma; F.A. Abd El-latif and Sohair M.E. Sadik (2003). Agricultural chemical, technological studies on sugar beet. 2- Effect of nitrogen application on yield, chemical constituents and juice quality characteristics of sugar beet. J. Agric. Sci. Mansoura Univ., 28 (3): 1853-1864.

Snedecor, G.W. and W.C. Cochran (1989). Statistical Methods. $8^{\text {th }}$ ed., lowa State Univ., Press Ames, lowa, USA.

Zalat, S.S. and Liala M. Saif (1997). Effect of nitrogen application and harvesting dates on yield and quality of sugar beet (Beta vulgaris, L.). Egypt. J. of Appl. Sci., 12(3): 88-93. 
تأثير معدل وميعاد اضـافة النيتروجين على انتاجية بنجر السكر تحث نظام الرى الرى

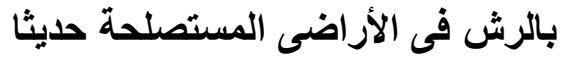

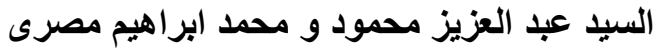
قسم المحاصيل- كلية الزراعة- جامعة القاهرة

نفذت تجربتان حقليتان فى أرض الخريجين بمنطقة سدمنت الجبل بمحافظة بنى سويف

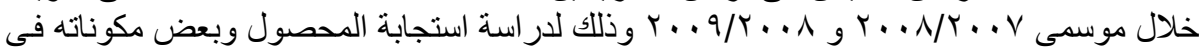

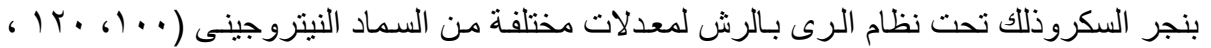

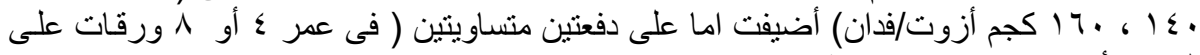

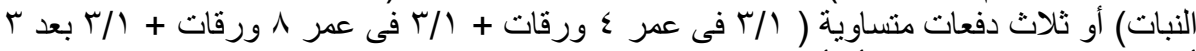

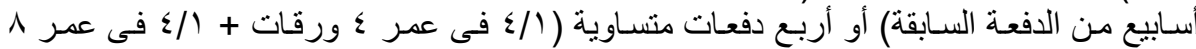

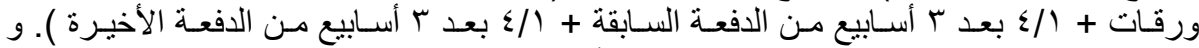

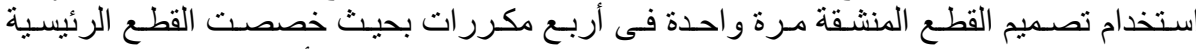

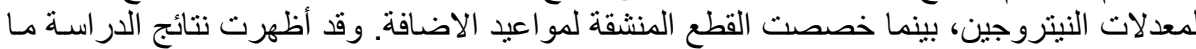

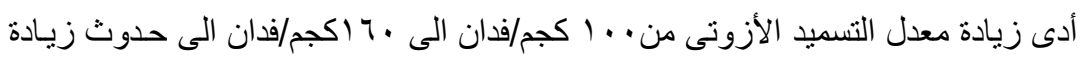

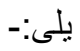

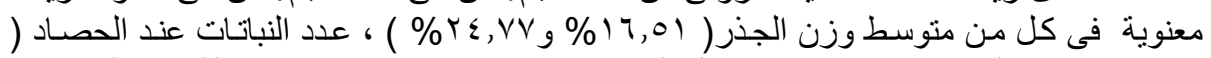

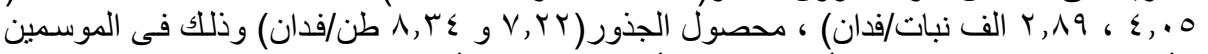

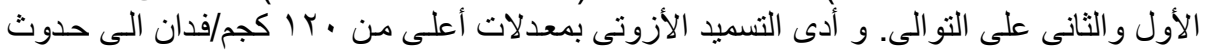

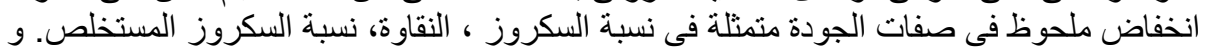

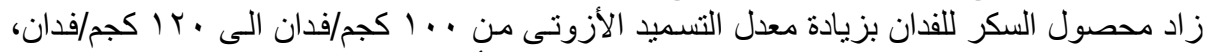

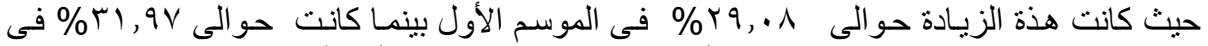

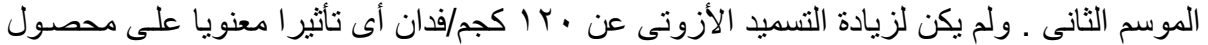

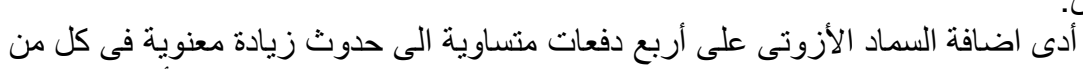

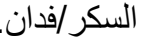

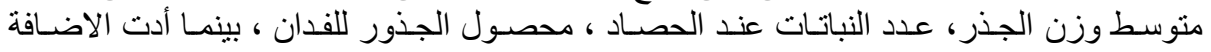

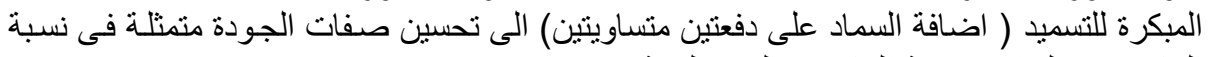

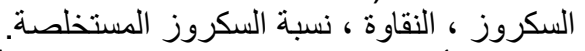

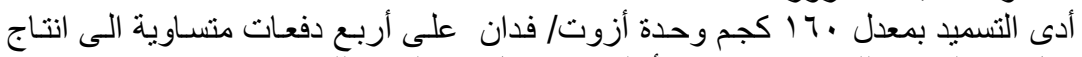

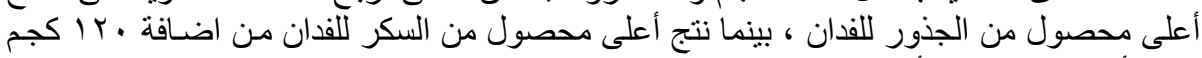
وحدة أزوت/فدان على أربع دفعات منساوية. 